\title{
Exhaled nitric oxide, serum ECP and airway responsiveness in mild asthmatic children
}

\author{
G.L. Piacentini", A. Bodini", S. Costella*, Y. Suzuki", L. Zerman", C.G.B. Peterson**, A.L. Boner ${ }^{\#}$
}

Exhaled nitric oxide, serum ECP and airway responsiveness in mild asthmatic children treated or untreated with inhaled steroids. G.L. Piacentini, A. Bodini, S. Costella, Y. Suzuki, L. Zerman, C.G.B. Peterson, A.L. Boner. ERS Journals Ltd 2000.

ABSTRACT: The purpose of the present study was to assess the possible relationships between exhaled nitric oxide (ENO), a circulating marker of eosinophil activation, serum eosinophil cationic protein (SECP), level of airway responsiveness to methacholine and lung function in asthmatic children, as well as to compare these markers between children with and without inhaled steroid therapy.

In a cross-sectional study ENO, SECP and bronchial hyperresponsiveness to methacholine were evaluated in a group of 57 asthmatic children (21 without and 36 with regulator inhaled steroid therapy; aged 6-13 yrs).

ENO was significantly lower in steroid treated children $(p<0.01)$. No significant differences between steroid treated and untreated children were observed for the provocative concentration of methacholine causing a $20 \%$ faill in forced expiratory volume in one second (FEV1; PC20), SECP and FEV1. In the whole study population significant increase correlations were observed between PC20 and SECP $(r=-0.329$, $\mathrm{p}=0.013)$ and between $\mathrm{ENO}$ and $\mathrm{FEV} 1 \%$ of predicted $(\mathrm{r}=-\mathbf{0 . 3 4 8}, \mathrm{p}<0.01)$. In the group not receiving inhaled steroids the inverse relationship between PC20 and SECP was more evident $(r=-0.581, p<0.001)$. In the steroid-treated group a significant inverse relationship was observed between ENO and FEV1 $(r=-0.426, p=0.0011)$.

The level of exhaled nitric oxide and the relationships between lung function, bronchial reactivity and markers of inflammation are different between steroidtreated and untreated asthmatic children. This has implications for the monitoring of asthma in childhood.

Eur Respir J 2000; 15: 839-843.
${ }^{\#}$ Clinica Pediatrica, Universita di Verona, Verona, Italy. *Istituto Pio XII, Misurina, Belluno, Italy. **Pharmacia \& Upjohn Diagnostics AB, Uppsala, Sweden.

Correspondence: A.L. Boner

Clinica Pediatrica

Policlinico Borgo Roma

37134 Verona

Italy

Fax: 39458200993

Keywords: Airway inflammation airway responsiveness

childhood asthma

markers of airway inflammation

nitric oxide

serum eosinophil cationic protein

Received: August 31999

Accepted after revision January 202000
The relationship between airway inflammation and airway responsiveness has been evaluated by different groups with contrasting results. Some authors [1-6] have found a strong relationship between inflammatory cells in the airway and the level of bronchial responsiveness while others failed to find such a correlation [7-11].

Similarly, contrasting results have been found between serum markers of eosinophil activation, in particular serum eosinophil cationic protein (SECP), and the degree of bronchial responsiveness in asthmatic patients [12-15].

Recently, the measurement of exhaled nitric oxide (ENO) has been proposed as a noninvasive means for assessing the degree of airway inflammation [16-18]. Some studies have evaluated the effect of treatment with inhaled steroids on the levels of ENO in asthmatic adults $[19,20]$ and one study in children with acute asthma [21]. Furthermore, a few studies have evaluated the relationship of this parameter with the level of airway hyperresponsiveness with contrasting results [22-25].

The purpose of the present study was to assess the possible relationship between ENO, a circulating marker of eosinophil activation SECP, level of bronchial hyperresponsiveness (BHR) to methacholine and lung function in asthmatic children, as well as to compare these markers between patients with and without inhaled steroid treatment.

\section{Material and methods}

\section{Subjects and study design}

Fifty-seven children with mild to moderate asthma, clinically stable, ranging 6-13 yrs of age, were recruited at the residential house "Istituto Pio XII" (Misurina, BL, Italy), located at an altitude of $1,756 \mathrm{~m}$ in the Italian Alps. All of the children were skin-prick test positive to inhaled allergens. Fifty-four were sensitized to, at least, house dust mite, and 41 of them were also positive to pollens, molds or furred pets. Three patients were not positive to house dust mite, but they were sensitized to pollens (one patient), molds (one patient) or pollens, molds and furred pets (one patient).

Twenty-one patients were not receiving any regular therapy for asthma, except $\beta_{2}$-agonists as needed, whereas 36 children were under regular treatment with inhaled steroids for at least 6 months. The dosage range for inhaled steroids was Beclomethasone 200-400 $\mu \mathrm{g} \cdot \mathrm{day}^{-1}$ and Fluticasone 100-200 $\mu \mathrm{g} \cdot \mathrm{day}^{-1}$. Inhaled $\beta_{2}$-agonists were not allowed for at least $12 \mathrm{~h}$ before entry into the study.

None of the patients had respiratory tract infections for at least 1 month before the beginning of the study. All of them had to present a fall in forced expiratory volume in one second $(\mathrm{FEV} 1)>20 \%$ after methacholine bronchial provocation (see method below). 
The study was approved by the Istituto Pio XII Ethics Committee, and both the children and their parents gave their consent to entering the trial. This was a cross-sectional study. ENO, SECP, spirometric values and the level of BHR to inhaled methacholine were measured.

\section{Lung function and methacholine provocation test}

FEV1 was measured by a dry spirometer (Compact Vitalograph, Buckingham, Buckinghamshire, UK). The best of three manoeuvres was recorded and actual values as well as percentage of predicted values were considered.

BHR was evaluated by methacholine bronchial provocation [26-28] performed by a MeFar dosimeter (MeFar, Brescia, Italy) [26]. The provocative concentration of methacholine required to produce a FEV1 fall of $20 \%$ $\left(\mathrm{PC} 20 \mathrm{mg} \cdot \mathrm{mL}^{-1}\right)$ was calculated [28].

\section{Nitric oxide measurement}

Exhaled NO was measured by a chemiluminescence analyser (LR 2149; Logan, Rochester, Kent, UK) [29, 30]. Briefly, the subjects were asked to perform a single slow exhalation through a mouthpiece, against a resistance and with a biofeedback used to maintain a steady controlled flow. This method allows the separation of the nasopharynx from the oropharynx by the soft palate, therefore preventing the contamination of ENO with nasal nitric oxide (NO). This method has been shown to be successfully applicable both in adults and in children. NO value was measured at the plateau of the end-exhaled reading and expressed in parts per billion according to guidelines [31]. Values of NO considered in the data analysis were always measured in the last part of exhalation (plateau exhaled NO), taking the plateau of the end-exhaled carbon dioxide reading as representative of an alveolar sample [20, 30-34].

\section{Serum eosinophil cotionic protein}

SECP was measured by means of a Pharmacia CAP System R) (ECP FEIA; Pharmacia \& Upjohn, Uppsala, Sweden) according to the manufacturers' instructions. Samples were analysed in duplicate. The inter- and intra-assay coefficient of variation were $<5 \%$ and the detection limit was $0.5 \mu \mathrm{g} \cdot \mathrm{L}^{-1}$. Serum was obtained after allowing venous blood toclot for $60 \mathrm{~min}$ at $20 \mathrm{C}$, followed by ic centrifugation at $4{ }^{\circ} \mathrm{C}$ and $1,600 \times g$.

\section{Statistical analysis}

Data are expressed both as mean $\pm \mathrm{SD}$ and as median, lower and upper quartile (Q1, Q3). PC20 values were logtransformed before performing statistical analysis. In those patients in whom a fall in FEV1 of $>20 \%$ from baseline was observed after saline, PC20 was considered 0 . In order to include these patients in the statistical analysis, starting the $\log$ PC20 scale $0,+1$ was added to all PC20 values before log-transformation [35].
Differences in the evaluated parameters between steroidtreated or untreated patients were evaluated by MannWhitney U-test. Correlations between the levels of BHR and NO measurements at baseline were tested by Spearman correlation test with $\mathrm{r}$ - and $\mathrm{p}$-values corrected for ties.

\section{Results}

The median values of the various parameters for the whole study population are shown in figure 1. Significant inverse correlations were observed between PC20 and SECP ( $\mathrm{r}=-0.329, \mathrm{p}=0.013$ ) (fig. 2a) and between ENO and $\mathrm{FEV} 1 \%$ predicted $(\mathrm{r}=-0.348, \mathrm{p}<0.01)$ (fig. $2 \mathrm{~b}$ ).

Significant differences between children not receiving steroid treatment versus steroid-treated children were observed only for ENO levels which were higher in the former $(\mathrm{p}=0.0024)$. In contrast, no significant differences between the groups were observed for PC20, SECP and FEV1\% (fig. 1).

In the group not receiving inhaled steroids the inverse relationship between $\mathrm{PC} 20$ and SECP $(\mathrm{r}=-0.581, \mathrm{p}<0.001)$ was confirmed (fig. 3). No other significant correlation was observed. In the steroid-treated group the only significant relationship was that observed between ENO and FEV1 ( $r=-0.426, p=0.0011$; fig. 4). a)

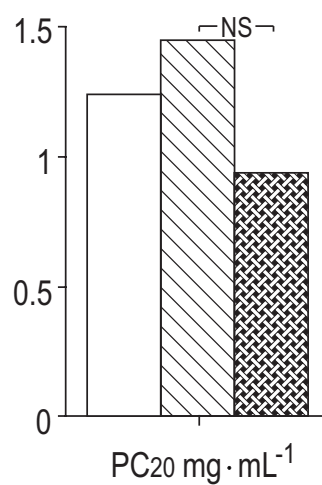

c)

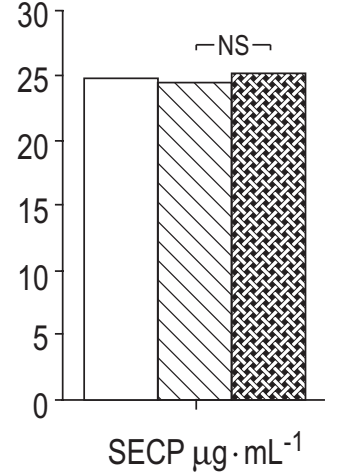

b)

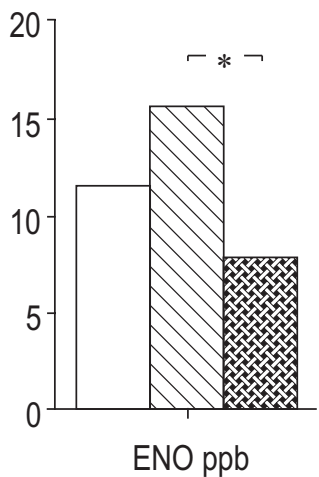

d)

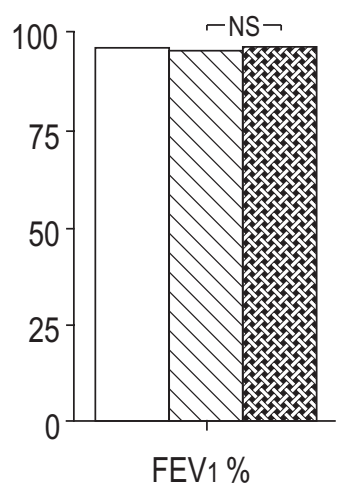

Fig. 1. - Median values (with range) for methacholine: a) provocative concentration causing a $20 \%$ fall in forced expiratory volume in one second (FEV1; PC20); b) exhaled nitric oxide (ENO); serum eosinophil cationic protein (SECP) and d) (FEV1). $\square$ : all subjects; $\mathbb{\mathbb { Q }}$ : no inhaled steroids; : inhaled steroids. The ranges of PC20 values were $\square: 0.59$ 3.75; $\mathbb{\mathbb { N } :}$ 0.89-3.81; $:$ : $0.53-3.50$. The ranges of ENO values were: $\square$ : $7.0-18.1 ; \mathbb{N}: 11.5-18.8$; 준 $5.9-15.3$. The ranges of FEV1 were: $\square$ : $89.5-105.7$; $\mathbb{\$}: 86.7-105$; $:$ : $84.3-108.5$. The ranges of SECP were: $\square: 14.6-32.3 ; \mathbb{\$}: 16.4-29.8 ;$ : 14.3-32.9. 

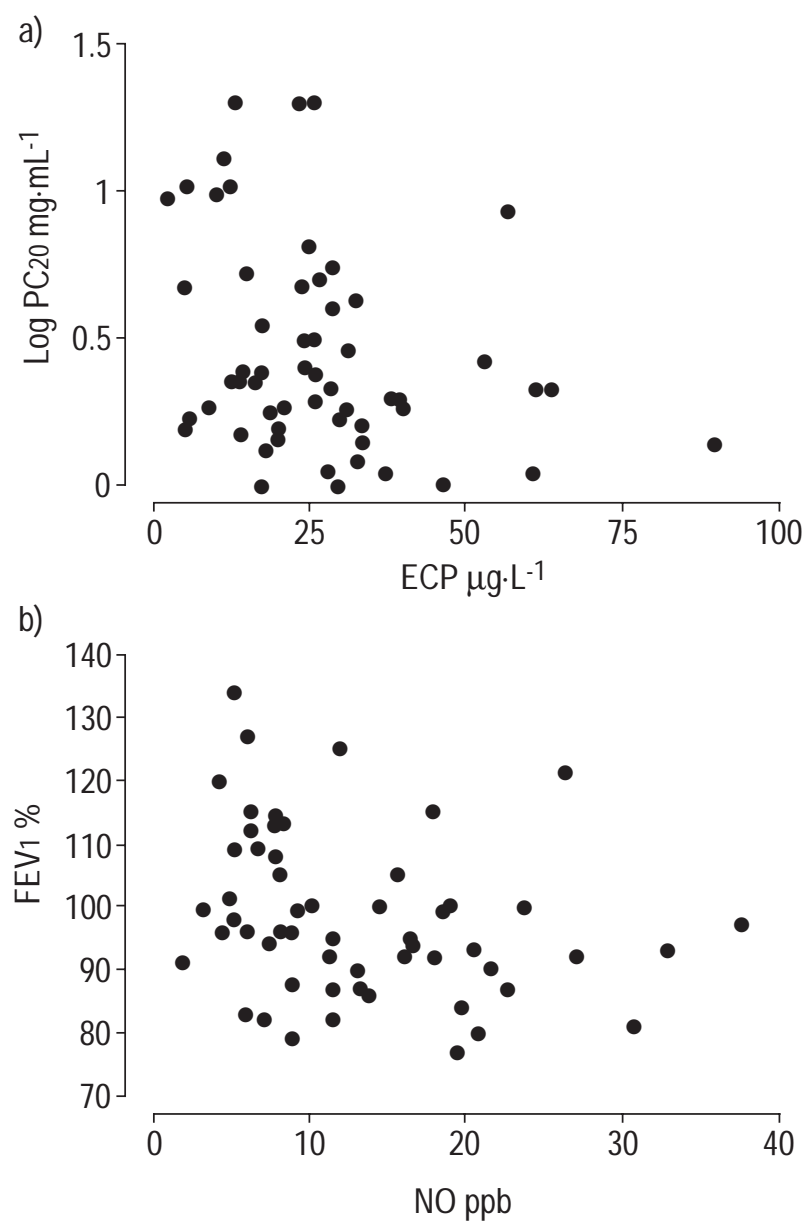

Fig. 2. - Correlation between provocative concentration causing a $20 \%$ fall in forced expiratory volume in one second (FEV1; PC20) and serum eosinophil cationic protein (SECP) $(\mathrm{r}=-0.33, \mathrm{p}=0.013)$, and between exhaled nitric oxide (ENO) and FEV1 $(\mathrm{r}=-0.35, \mathrm{p}<0.01)$, in the whole study population. ppb: parts per billion.

\section{Discussion}

This study examined the relationships between lung function, BHR, ENO and SECP in clinically stable children with mild-to-moderate asthma treated or untreated with inhaled steroids and resident in an environment free of offending allergens.

Considering all subjects together, significant inverse correlations were observed as expected both between PC20, FEV1, peak expiratory flow and SECP as well as between ENO and FEV1. However, these relationships were differently expressed when the study population was divided into steroid-treated and untreated subjects, thus suggesting that the effect of inhaled steroids is particularly effective on ENO levels.

The correlation between SECP and BHR is in agreement with previous findings $[5,36,37]$. This concordance may reflect a degree of predisposition for eosinophils to be activated, possibly related to the level of BHR $[4,5,36,37]$. In this study, in spite of a significant relationship in the whole group of subjects, the best concordance was found in the steroid-untreated children. In contrast, when the steroidtreated patients were analysed separately, this concordance was definitely lost (table 1). The lack of a significant relationship observed in the children receiving inhaled steroids

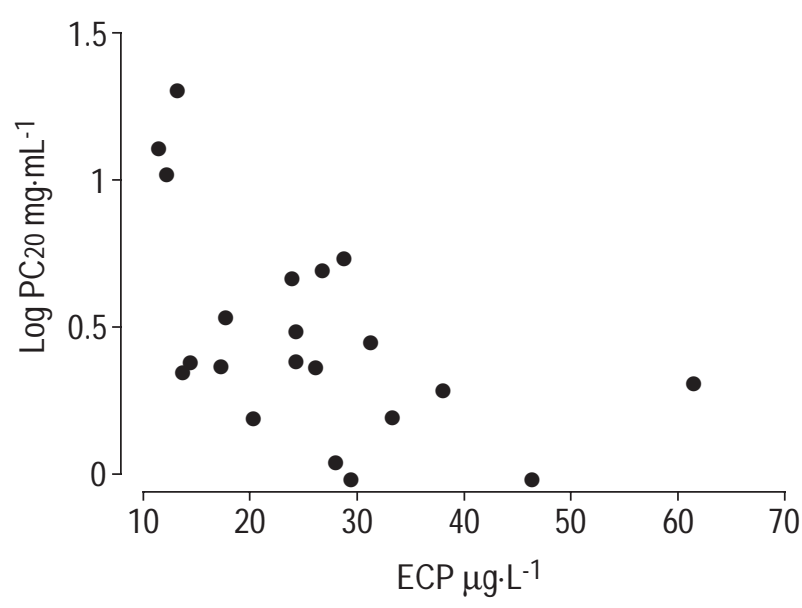

Fig. 3. - Correlation between the provocative concentration causing a $20 \%$ fall in forced expiratory volume in one second (FEV1; PC20) and serum eosinophil cationic protein (SECP) in the subgroup not receiving inhaled steroids $(\mathrm{r}=-0.58, \mathrm{p}<0.01)$.

may suggest that the treatment could affect, to different extents, the degrees of airway reactivity and of eosinophil activation. This apparent discrepancy cannot be completely unexpected, since, although eosinophils are the most representative cell type of asthma, airway inflammation in this disease is a dynamic phenomenon to which different cell types mutually contribute [38] and inflammation is not the only factor responsible for BHR [39].

Similarly, the significant correlations between ENO and FEV1 observed in the group in toto and in the steroidtreated patients suggest a link between the level of the airway inflammation associated with NO production and lung function. Nevertheless, the relationship between ENO and FEV1 is a contrasting issue in the literature with some studies showing a significant correlation $[18,25,40]$, whereas others failed to show such a correlation [23]. In the study by ARTLICH et al. [18], the children showing a relationship between ENO and FEV1, were receiving anti-inflammatory treatment, either cromolyn or inhaled steroids. Therefore, they received a treatment similar to the children treated with low dose inhaled steroids in the present study. Unfortunately in that study the authors did not measure the level of BHR [18]. In contrast, the group of adults studied by JATAKANON et al. [23], for which no significant correlation was observed between ENO and FEV1, was more similar to the group of untreated children in our study population, both for treatment and for level of BHR. It may be possible that in the relatively more severe subjects, for whom a regular anti-inflammatory treatment was necessary, the measurement of airway flow is less sensitive in evaluating the severity of the disease as compared to airway inflammation as evaluated by ENO. This is in agreement with the finding by KARITONOV and coworkers $[19,20]$ who showed that significant changes of ENO levels induced by the introduction of treatment with budesonide [20] or mod-ulation of its dosage [19] were not accompanied by signi-ficant modifications in FEV1 levels.

Exhaled NO, was significantly lower in the group of children receiving a regular course of inhaled steroids irrespective of $\mathrm{PC} 20$ methacholine value. In contrast, lung function and SECP were very similar in the two groups of 


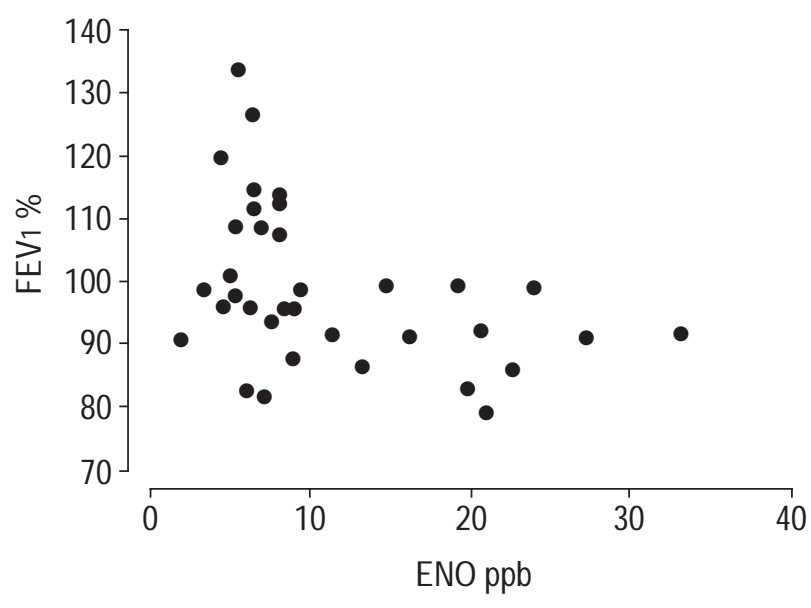

Fig. 4. - Correlation between exhaled nitric oxide (ENO) and forced expiratory volume in one second (FEV1) in the subgroup treated with inhaled steroids $(\mathrm{r}=-0.426, \mathrm{p}=0.012)$. ppb: parts per billion.

patients (fig. 1). BHR tended to be slightly higher in the steroid-treated children, but the difference failed to be statistically significant. The lower level of ENO, despite a slightly higher BHR to methacholine in the steroid-treated group, as compared to the untreated group, may suggest that inhaled steroid can have a greater efficacy in reducing the level of airway inflammation than in treating BHR in asthmatic children. Conversely, the untreated subjects, who are not more hyperreactive than the treated ones, presented a significantly higher level of ENO, suggesting a higher degree of airway inflammation in this group. Also in this case, a discrepancy between the level of BHR and airway inflammation should not be unexpected given the complexity of the mechanisms underlying the final phenotypic expression of airway responsiveness in asthmatic patients $[39,41]$. Inhaled steroids have been hypothesized to be effective in reducing ENO by direct inhibition of inducible nitric oxide synthase expression in the airway with a concomitant effect resulting in an inhibition of the bronchial inflammation in asthmatic patients [42]. The possible discordance between inflammation and BHR levels in steroid-treated children can be in part sup-

Table 1. - Relationships between the investigated parameters in the steroid-treated and steroid-untreated children

\begin{tabular}{lcccccc}
\hline & PC20 & NO & SECP & FEV1 & FEF25-75 & PEF \\
\hline PC20 & & \multirow{2}{*}{ NS } & $\mathrm{r}=-0.58$ & NS & $\mathrm{r}=0.49$ & NS \\
& & & $\mathrm{p}<0.001$ & & $\mathrm{p}=0.029$ & \\
NO & NS & & NS & NS & NS & NS \\
SECP & NS & NS & & NS & NS & NS \\
FEV1 & NS & r=-0.43 & NS & & $\mathrm{r}=0.66$ & $\mathrm{r}=0.49$ \\
& & $\mathrm{p}=0.012$ & & & $\mathrm{p}=0.03$ & $\mathrm{p}<0.05$ \\
FEF25-75 & NS & NS & NS & $\mathrm{r}=0.022$ & & NS \\
& & & & $\mathrm{p}=0.39$ & & \\
PEF & NS & NS & $\mathrm{r}=0.481$ & $\mathrm{r}=0.60$ & $\mathrm{NS}$ & \\
& & & $\mathrm{p}=0.024$ & $\mathrm{p}=0.005$ & & \\
\hline
\end{tabular}

PC20: provocative concentration of methacholine required to produce a $20 \%$ fall in forced expiratory volume in one second (FEV1); NO: nitric oxide; SECP: serum eosinophil cationic protein; FEF25-75: forced mid-expiratory flow; PEF: peak expiratory flow; Ns: nonsignificant. ported by the data from a recent study in an animal model that shows that beclomethasone can prevent virusinduced airway inflammation but not hyperresponsiveness [43]. As an alternative explanation, BHR values may suggest that some of the patients receiving steroids still had an ongoing "subclinical" inflammation. This could also indicate that NO might not fully reflect the inflammation in the airway but mainly the effect of steroids locally in the lower airway, e.g. on epithelial cells and macrophages. In this case ENO should be considered a too sensitive parameter for the evaluation of airway inflammation in asthmatic patients.

Long-term prospective studies with repeated evaluations of lung function, airway reactivity and inflammation will allow a better insight of the causal and temporal relationships amongst the characteristic pathogenetic features of bronchial asthma, as well as their clinical significance.

\section{References}

1. Wardlaw AJ, Dunnette S, Gleich GJ, Collins JV, Kay AB. Eosinophils and mast cells in bronchoalveolar lavage in subjects with mild asthma: relationship to bronchial hyperreactivity. Am Rev Respir Dis 1988; 137: 62-69.

2. Azzawi M, Bradley B, Jeffery PK, et al. Identification of activated $\mathrm{T}$ lymphocytes and eosinophils in bronchial biopsies in stable atopic asthma. Am Rev Respir Dis 1990; 142: 1407-1413.

3. Kirby JG, Hargreave FE, Gleich GJ, O'Byrne PM. Bronchoalveolar cell profiles of asthmatic and nonasthmatic subjects. Am Rev Respir Dis 1987; 136: 379-383.

4. Bentley AM, Menz G, Storz D, et al. Identification of T lymphocytes, macrophages, and activated eosinophils in the bronchial mucosa in intrinsic asthma: relationship to symptoms and bronchial responsiveness. Am Rev Respir Dis 1992; 146: 500-506.

5. Walker C, Kaegi MK, Braun P, Blaser K. Activated T cell and eosinophilia in bronchoalveolar lavages from subjects with asthma correlated with disease severity. J Allergy Clin Immunol 1991; 88: 935-942.

6. Bradley BL, Azzawi M, Jacobson M, et al. Eosinophils, T-lymphocytes, mast cell, neutrophils, and macrophages in bronchial biopsy specimens from atopic subjects with asthma: comparison with biopsy specimens from atopic subjects without asthma and normal control subjects and relationship to bronchial hyperresponsiveness. J Allergy Clin Immunol 1991; 88: 661-674.

7. Ollerenshaw SL, Woolcock AJ. Characteristics of the inflammation in biopsies from large airway of subjects with asthma and subjects with chronic airflow limitation. $\mathrm{Am}$ Rev Respir Dis 1992; 145: 922-927.

8. Djukanovic R, Wilson JW, Britten KM, et al. Quantitation of mast cells and eosinophils in the bronchial mucosa of symptomatic atopic asthmatics and healthy control subjects using immunohistochemistry. Am Rev Respir Dis 1990; 142: 863-871.

9. Ferguson AC, Wong FW. Bronchial hyperresponsiveness in asthmatic children: correlation with macrophages and eosinophils in broncholavage fluid. Chest 1989; 96: 988991.

10. Jeffery PK, Wardlaw AJ, Nelson FC, Collins JV, Kay AB. Bronchial biopsies in asthma: an ultrastructural, quantitative study and correlation with hyperreactivity. Am Rev Respir Dis 1989; 140: 1745-1753.

11. Adelroth E, Rosenhall L, Johansson SA, Linden M, 
Venge P. Inflammatory cell and eosinophilic activity in asthmatics investigated by bronchoalveolar lavage: the effects of antiasthmatic treatment with budesonide or terbutalide. Am Rev Respir Dis 1990; 142: 91-99.

12. Ferdousi HA, Dreborg S. Asthma, bronchial hyperreactivity and mediator release in children with birch pollinosis. ECP and EPX levels are not related to bronchial hyperreactivity. Clin Exp Allergy 1997; 27: 530-539.

13. Ferguson AC, Vaughan R, Brown H, Curtis C. Evaluation of serum eosinophil cationic protein as a marker of disease activity in chronic asthma. J Allergy Clin Immunol 1995; 95: 23-28.

14. Riise GC, Andersson B, Ahlstedt S. Bronchial brush biopsies for studies of epithelial inflammation in stable asthma and nonobstructive chronic bronchitis. Eur Respir $J$ 1996; 9: 1665-1671.

15. Hoekstra MO, Hovenga H, Gerritsen J, Kauffman HF. Eosinophils and eosinophil-derived protein in children with moderate asthma. Eur Respir J 1996; 9: 2231-2235.

16. Kharitonov SA, Barnes PJ. Exhaled nitric oxide: a marker of inflammation? Curr Opin Anaesthesiol 1996; 9: 542548.

17. Alving K, Weitzberg E, Lundberg JM. Increased amount of nitric oxide in exhaled air of asthmatics. Eur Respir $J$ 1993; 6: 1368-1370.

18. Artlich A, Hagenah JU, Jonas S, Ahrens P, Gortner L. Exhaled nitric oxide in childhood asthma. Eur J Pediatr 1996; 155: 698-701.

19. Kharitonov SA, Yates DH, Chung KF, Barnes PJ. Changes in the dose of inhaled steroid affect exhaled nitric oxide levels in asthmatic patients. Eur Respir J 1996; 9: 196-201.

20. Kharitonov SA, Yates DH, Barnes PJ. Inhaled glucocorticoids decrease nitric oxide in exhaled air of asthmatic patients. Am J Respir Crit Care Med 1996; 153: 454-457.

21. Baraldi E, Azzolin NM, Zanconato S, Dario C, Zacchello F. Corticosteroids decrease exhaled nitric oxide in children with acute asthma. $J$ Pediatr 1997; 131: 381-386.

22. Garnier P, Fajac I, Dessanges JF, Dall'Ava-Santucci J, Lockhart A, Dinh-Xuan AT. Exhaled nitric oxide during acute changes of airways calibre in asthma. Eur Respir $J$ 1996; 9: 1134-1138.

23. Jatakanon A, Lim S, Kharitonov SA, Chung KF, Barnes PJ. Correlation between exhaled nitric oxide, sputum eosinophils, and methacholine responsiveness in patients with mild asthma. Thorax 1998; 53: 91-95.

24. Dupont LJ, Rochette F, Demedts MG, Verleden GM. Exhaled nitric oxide correlates with airway hyperresponsiveness in steroid-naive patients with mild asthma. Am J Respir Crit Care Med 1998; 157: 894-898.

25. Jatakanon A, Lim S, John M, et al. Effect of inhaled budesonide on lung function and airway inflammation: assessmant by various inflammatory markers in mild asthma. Am J Respir Crit Care Med 1999; 159: 22-30.

26. Piacentini GL, Martinati L, Fornari A, et al. Antigen avoidance in a mountain environment: influence on basophil releasability in children with allergic asthma. $J$ Allergy Clin Immunol 1993; 92: 644-650.

27. Hargreave FE, Ryan G, Thomson NC. Bronchial responsiveness to histamine or methacholine in asthma: measur- ement and clinical significance. J Allergy Clin Immunol 1981; 68: 347-355.

28. Sterk PJ, Fabbri LM, Quanjer PH, et al. Airway responsiveness. Standardized challenge testing with pharmacolological, physical and sensitizing stimuli in adults. Report of the Working Party Standardization of Lung Function tests, European Community for Steel and Coal. Official Statement of the European Respiratory Society. Eur Respir J 1993; 6: Suppl. 16, 53-83.

29. Barnes PJ, Kharitonov SA. Exhaled nitric oxide: a new lung function test. Thorax 1996; 51: 233-237.

30. Kharitonov SA, Chung KF, Evans D, O'Connor BJ, Barnes PJ. Increased exhaled nitric oxide in asthma is mainly derived from the lower respiratory tract. $A m J$ Respir Crit Care Med 1996; 153: 1773-1780.

31. Kharitonov SA, Alving K, Barnes PJ. Exhaled and nasal nitric oxide measurements: recommendations. Eur Respir $J$ 1997; 10: 1683-1693.

32. Lundberg JON, Weitzberg E, Lundberg JM, Alving K. Nitric oxide in exhaled air. Eur Respir J 1996; 9: 26712680.

33. Byrnes CA, Dinarevic S, Shinebourne EA, Barnes PJ, Bush A. Exhaled nitric oxide measurements in normal and asthmatic children. Pediatr Pulmonol 1997; 24: 312-318.

34. van der Mark ThW, Kort E, Meijer RJ, Postma DS, Koeter GH. Water vapour and carbon dioxide decrease nitric oxide readings. Eur Respir J 1997; 10: 2120-2123.

35. Van Schayck CP, Graafsma SJ, Visch MB, Dompeling E, van Weel $C$, van Herwaarden CLA. Increased bronchial hyperresponsiveness after inhaling salbutamol during 1 year is not caused by subsensitization to salbutamol. $J$ Allergy Clin Immunol 1990; 86: 793-800.

36. Fernivik E, Gronneberg R, Lundahl J. The degree of natural allergen exposure modifies eosinophil activity markers in the circulation of patients with mild asthma. Allergy 1996; 51: 697-705.

37. Hansel TT, Braunstein JB, Walker C. Sputum eosinophils from asthmatics express ICAM-1 and HLA-DR. Clin Exp Immunol 1991; 86: 271-277.

38. Kips JC, Pauwels RA. Serum eosinophil cationic protein in asthma: what does it mean? Clin Exp Allergy 1998; 28: $1-3$.

39. Haley KJ, Drazen JM. Inflammation and airway function in asthma. Am J Respir Crit Care Med 1998; 157: 1-3.

40. ten Hacken NHT, Meijer RJ, Kerstjens HAM, van der Mark ThW. Expired Nitric Oxide in Stable Asthmatic Patients does not Relate to Parameter of Disease Severity. Eur Respir J 1996; 9: Suppl. 23, 416s.

41. Taylor DA, Lim S, Barnes PJ, O'Connor BJ. Exhaled Nitric Oxide Production and Increased Airway Responsiveness in Asthma Reflect Different Inflammatory Pathways. Eur Respir J 1996; 9: Suppl. 23, 416s-417s.

42. Barnes PJ, Liew FY. Nitric oxide and asthmatic inflammation. Immunol Today 1995; 9: 416S.

43. Leusink-Muis A, Ten Broeke R, Folkerst G, De Clerck F, Nijkamp FP. Beclomethasone prevents virus-induced airway inflammation but not airway hyperresponsiveness in guinea pigs. Clin Exp Allergy 1999; 29(Suppl. 2): 8285 . 